\title{
Silk road archipelagos: Islands in the Belt and Road Initiative
}

\author{
Adam Grydehøj \\ Island and Coastal Zone Institute, Urban and Rural Innovation Design Research Center, \\ Zhejiang University, China \\ Island Dynamics, Denmark \\ agrydehoj@islanddynamics.org
}

Sasha Davis

Keene State College, USA

sasha.davis@keene.edu

\section{Rui Guo}

College of Civil Engineering and Architecture, Zhejiang University, China 11812014@zju.edu.cn

\section{Huan Zhang \\ School of Civil Engineering and Architecture, Zhejiang University, China 0014979@zju.edu.cn (corresponding author)}

\begin{abstract}
The concept behind the Belt and Road Initiative (BRI; formerly 'One Belt, One Road') began to take shape in 2013. Since then, this Chinese-led project has become a major plank in China's foreign relations. The BRI has grown from its basis as a vision of interregional connectivity into a truly global system, encompassing places-including many island states, territories, and cities - from the South Pacific to the Arctic, from East Africa to the Caribbean, from the Indian Ocean to the Mediterranean. Islands and archipelagos are particularly prominent in the BRI's constituent $21^{\text {st }}$-Century Maritime Silk Road (MSR) and Polar Silk Road or Ice Silk Road projects, but little scholarly attention has been paid to how the BRI relates to islands per se. This special section of Island Studies Journal includes nine papers on islands and the BRI, concerning such diverse topics as geopolitics, international law and territorial disputes, sustainability and climate change adaptation, international relations of autonomous island territories, development of outer island communities, tourism and trade, and relational understandings of archipelagic networks. Taken together, these papers present both opportunities and risks, challenges and ways forward for the BRI and how this project may impact both China and island and archipelago states and territories.
\end{abstract}

Keywords: archipelagos, China, Belt and Road Initiative (BRI), islands, $21^{\text {st }}$-Century Maritime Silk Road

https://doi.org/10.24043/isj.137 • Received October 2020, accepted November 2020

(C) 2020-Institute of Island Studies, University of Prince Edward Island, Canada. 


\section{Introduction}

In a pair of speeches in September and October 2013, Chinese President Xi Jinping announced what would come to be known as the 'Belt and Road Initiative' (BRI; formerly 'One Belt, One Road'). In March 2015, China's National Development and Reform Commission, Ministry of Foreign Affairs, and Ministry of Commerce (2015) issued Vision and actions on jointly building Silk Road Economic Belt and 21st-Century Maritime Silk Road, a document that set forth the overall concept and content of the BRI as an initiative promoting economic prosperity and regional economic cooperation, principles of mutual consultation, joint construction and sharing, policy coordination, and mutually beneficial development.

Originally envisioned as being composed of the overland 'Silk Road Economic Belt' and the oceanic '21st-Century Maritime Silk Road', the BRI has since expanded to encompass a vast array of projects and regions, including the creation of a 'Polar Silk Road' or 'Ice Silk Road' (Blaxekjær, Lanteigne, \& Shi, 2018; Lim, 2018) and the extension of the MSR out toward the islands of the South Pacific. The BRI is open, inclusive, and flexible in the sense that it has come to include states from around the world, interacting with China and with one another at a range of intensities and scales and from a range of directions. Through its creation and promotion of the BRI, China has significantly altered its approach to the world, offering major opportunities for the promotion of Chinese interests and capital (Zhang, 2017).

As the BRI has gained increasing prominence in Chinese policymaking and economic planning, state and business actors from other countries have increasingly co-opted and adapted the BRI vision in an attempt to steer their way into Chinese investment streams and benefit from infrastructural, transport, and strategic synergies. By the same token though, other state actors have used the breadth and power of the BRI concept as a political lever for signalling distance from China and opposition to what is cast as Chinese imperialism. The BRI has thus become a field of complex geopolitical engagement (Blanchard \& Flint, 2017), part of wider shifts in economic, political, and discursive influence, which are fundamentally impacting the ways in which island communities are locating their place in the world (Davis, 2020).

\section{What is the Belt and Road Initiative?}

While most commentators recognize that the BRI has genuine and far-reaching impacts on the world, there is disagreement as to what the BRI actually is. Cai (2017) argues that the BRI is both a geostrategic and a geoeconomic programme or set of policies aimed at advancing Chinese interests. Flint and Zhu (2019) agree that the strategic and economic aspects of the BRI as inseparable but regard the BRI more as a "strategy" than as a policy. Liu and Dunford (2016) see the BRI as a "model" of inclusive, mutually beneficial globalisation. Zhou and Esteban (2018) describe the BRI variously as a "multifaceted grand strategy," "vehicle of soft balancing," and a "decisive strategic maneuver." Nordin and Weissmann (2018, p. 231) evaluate the BRI as a "strategic initiative" seeking to develop "networked capitalism" while focusing on "the Chinese national unit." Jones and Zeng (2019, p. 1416), for their part, argue that:

Projects like BRI are not meticulously planned by top leaders; rather, they are loose 'policy envelopes', whose parameters and implementation are shaped by internal 
struggles for power and resources. They are kept deliberately vague to accommodate these diverse interests, creating wide latitude for them to influence, interpret and even ignore top leaders' wishes. Accordingly, BRI is already unfolding in a fragmented, incoherent fashion, departing significantly from both its original design, in 2013, as part of 'periphery diplomacy', and from formal, top-level plans issued in 2015.

What all the above authors can agree on is that the BRI is not merely any one thing at any one time; it is many things simultaneously and can be considered from a variety of perspectives.

From the perspective of China's central government, the BRI may simultaneously be a means of guiding the overseas movement of Chinese capital, investment, and economic activity in particular, nationally beneficial directions; a means of creating new markets for Chinese goods and services; a means of challenging USA geopolitical dominance; and a means of promulgating a new vision of international 'win-win' cooperation (Zhang, 2018; Liu, Dunford, \& Gao, 2018). From the perspective of city and provincial governments in China, the BRI may represent a forum for inter-city and inter-provincial competition while also being an opportunity to benefit from national streams of investment, policy support, and diplomatic networks when pursuing localised interests (Zeng, 2019; Chen et al, 2019; He, 2018). For national and subnational governments in other countries, the BRI may be a means of attracting much-needed investment, technology, and know-how; a means of placing pressure on other (more traditional) trading partners; or even a means of signalling distance from the Chinese state (Herrero \& Xu, 2019; Damuri et al, 2019; Pant \& Passi, 2017). For people living in places in which BRI projects are being undertaken, whether in China or overseas, it may be impossible to perceive the BRI as a vast, abstract strategy, framework, model, or set of policies. For such communities, the BRI may attain more or less concrete manifestation in bridges, ports, schools, factories, immigration, pollution, and changing livelihood opportunities.

\section{Islands in the Belt and Road Initiative}

All the above aspects of the BRI appear in the papers that comprise this special section of Island Studies Journal. The BRI is in the eye of the beholder. Because it is so difficult to pin down the BRI as any one thing and to differentiate specific governmental, business, or individual activities as belonging to the BRI rather than just as part of pre-existing or other emergent streams of people-to-people and place-to-place relation, the BRI's positive and negative impacts can be difficult to assess with much accuracy or even discuss with much rigour.

We nevertheless find it productive to think with and about the BRI because the BRI, and particularly its $21^{\text {st }}$-Century Maritime Silk Road (MSR) component, has focused policy attention on many small island and archipelago states and territories that are usually regarded as peripheral to world politics. The flows of capital, people, diplomacy, and environmental impact formally and informally associated with the BRI are drawing even 'isolated' island societies such as Kiribati, Kalaallit Nunaat (Greenland), and Comoros ever more deeply into global processes. Concomitant with this, in addition to its potential social, economic, cultural, security, and political results, the BRI is in the process of creating and reshaping a wide range of island-island and island-mainland relations. This is not just coincidental but is at the core of the BRI's discursive roots in the (romantic) idea of a historical Silk Road trade route that 
connected civilisations of ancient and imperial China through to those of Central Asia, Western Asia, and Southern Europe (Winter, 2019). Through the BRI, formerly unconnected islands have entered into what we may interpret as a decentred network of archipelagic relation stretching between the island cities of Southern China (e.g. Guangzhou, Hainan, Hong Kong, Macao, Pingtan, Xiamen, Zhoushan, Zhuhai); the great archipelago states of Southeast Asia; the vast oceanic expanses of the South Pacific; the island communities of Russia, the Nordic World, and the Canadian Arctic; the islands of the Mediterranean, Red Sea, and Persian Gulf; and the diverse island countries of the Indian Ocean; and the islandrich Caribbean. Depraetere (2008) speaks of 'the World Archipelago', but the BRI may well be the first major attempt to 'activate' and foreground this archipelago, to foster a multitude of island-island and island-mainland connectivities.

Despite the mass of research concerning the BRI, relatively little attention has been paid to the project's geographical specificities and even less to how the BRI relates to islands per se. The present special section of Island Studies Journal represents a small step in this direction. This special section arose out of the Silk Road Archipelagos conference, held in Fuzhou, China, on 9-10 November 2019. The conference was organised by the Ministry of Natural Resources' Island Research Center, Island Dynamics, the Ministry of Education's Key Laboratory of Coastal Disaster and Defence (Hohai University), the Fuzhou Lawyers' Association's Foreign Commercial Division, and the Sea Law and Free Trade Port Area Construction Research Center. The conference was co-organised by Shanghai Ocean University's College of Marine Culture and Law, Fuzhou University's Institute of International Law Research, the Ministry of Transport's Tianjin Research Institute for Water Transport Engineering, Fujian Normal University's Law School, and the Research Center for South Pacific Island Countries.

\section{Contents of this section}

This special section consists of nine articles describing, analysing, and addressing the relationships between islands and the BRI. These studies advance new concepts, suggestions, and strategies for cooperative development of islands, both within and in relation to the BRI, and they do so from a variety of disciplinary perspectives.

Islands have long been sites of geopolitical contestation. Since the mid- $20^{\text {th }}$ Century and the rise in independent island states and autonomous island territories, geopolitical competition over islands with histories of colonisation has grown more complex. In the first article, 'Someone else's chain, someone else's road: U.S. military strategy, China's Belt and Road Initiative, and island agency in the Pacific', Sasha Davis, Lexi A. Munger, and Hannah J. Legacy (2020) assert the ability of island states and territories to pursue their own interests and not allow themselves to be squeezed into great power competition. They argue that island peoples and governments are capable of actively and skillfully handling relationships between multiple sources of influence, and use cases from Oceania to show that islands can advance their own agendas instead of being bound by maps drawn by great powers.

In the second article, 'Island territorial disputes and China's "Shelving Disputes and Pursuing Joint Development" policy', Tao Yu and Bingyao Li (2020) discuss Chinese state and scholarly approaches to island territorial disputes, regarding these as a stumbling block for international cooperative development. They argue that a Chinese policy focus over the past 
decades on 'sovereignty belongs to China' as a prerequisite for 'shelving disputes and achieving joint development' creates adversarial and antagonistic premises for conflict resolution and collaboration-without actually having much success in terms of 'winning' territorial disputes. The authors suggest that development of the MSR would be advanced by China adopting a more nuanced conceptualisation of sovereignty.

In the third article, 'Perceiving the Silk Road Archipelago: Archipelagic relations within the ancient and 21st-Century Maritime Silk Road', Baoxia Xie, Xianlong Zhu, and Adam Grydehøj (2020) emphasise that people's ways of conceiving the world have the potential to change the world, and they experiment with conceptualising the MSR as a decentred network of archipelagic relation. They argue that by seeing the ancient MSR as an interlinking of island communities, it is possible to productively imagine an MSR that brings together islanders with diverse needs but shared interests and connections. They also argue that such a perspective challenges antagonistic East/West binaries and oppositions.

The South Pacific, comprising 29 countries and regions and consisting of more than 10,000 islands, has become a significant extension to the MSR. Bilateral tourism economy and trade exchanges influence political and economic aspects of the relationships between China and South Pacific island countries. In the fourth article, "The relationship between China-South Pacific island countries tourism and trade in the context of the Belt and Road Initiative', Fang Ye, Jaepil Park, ChunLin Li, and Yixiong He (2020) use econometric methods and data analysis to study the dynamic relationship between long-term equilibrium of international tourism and trade. They ultimately offer three suggestions for promoting future bilateral cooperation based on the interaction between tourism and trade.

In the fifth article, Adrien Rodd (2020) discusses relations between China and Fiji in the context of the BRI. The paper shows why Fiji is working to actively participate in the BRI as a means of gaining developmental potential and strengthening its own rights and interests. This is occurring against a backdrop of power competition among major states, within which Fiji itself is seeking to become a leader among Pacific island countries.

In the sixth article, 'Indian Ocean island sustainable development in the context of the 21st-Century Maritime Silk Road', Shuneng Zhong and Xili Wu (2020) emphasise the necessity of taking into account unique island social and environmental needs in the development of a sustainable MSR. They consider whether the MSR can provide a diversified sustainable development model for Indian Ocean island countries, highlighting potentials for progress but also difficulties involved in assessing sustainability efforts and ensuring that the BRI vision is implemented on the ground.

In the seventh article, 'International linkages, geopolitics, and the Belt and Road Initiative: A comparison of four island territories', Ying-ho Kwong and Mathew Y.H. Wong (2020) compare two autonomous subnational island jurisdictions of China (Hong Kong and Macao) and two autonomous island territories of Denmark (Kalaallit Nunaat and Faroe) to consider the manner in which different islands may be more or less susceptible to influence from different great powers, namely China and the USA. They argue that subnational island jurisdictions that already have strong relations with countries beside their metropolitan powers have more choice when confronted by great power policies, while island territories with weaker international links may be more willing to accept great power policies that are perceived as offering them new opportunities. 
In the eighth article, 'The Maritime Silk Road's potential effects on outer island development: The Natuna Islands, Indonesia', Hertria Putri and Wilmar Salim (2020) analyse the economic, political, and geostrategic features and functions of outer islands as well as describe the developmental background of and practical difficulties faced by Indonesia's Natuna Islands. They suggest that the MSR could provide opportunities for such peripheral islands while noting, however, potential negative impacts. The authors argue that it is important that island communities be directly involved in MSR decisionmaking and processes to ensure that islanders' needs are met and that islands' resources are used in a sustainable manner.

In the ninth and final article, 'Island climate change adaptation and global public goods within the Belt and Road Initiative', Chunlin Li, Jianqing Chen, and Adam Grydehøj (2020) emphasise the manner in which sustainability and climate security represent global public goods, which are inadequately supplied by the existing international order, with its basis in national self-interest. The BRI has been envisioned by the Chinese state as a system for providing global public goods, yet it has thus far paid insufficient attention to the special yet diverse needs of island communities. The authors therefore propose an island-focused sustainable development framework for the BRI that can meet needs related to climate change adaptation, especially in the areas of information sharing, scientific and technological cooperation, financial support, and capacity building.

\section{Conclusion}

This special section helps shed light on both challenges and potentials connected with the BRI and how these relate to island states and territories, particularly in the Indian Ocean, South China Sea, and South Pacific.

The special section nevertheless has its limits. Like the BRI itself, despite its purportedly global scope, the research presented here largely originates from China. There is a relative lack of island perspectives. This is not because island perspectives are unavailable (Island Studies Journal as a whole is testament to the tremendous breadth and richness of island-centred research today) but, it seems, because the BRI remains primarily seen as a project grounded in Chinese interests. A BRI perspective is still likely to be regarded as a Chinese perspective, with island governments and peoples perhaps being willing to position some of their activities as part of the BRI for the sake of Chinese actors but more generally seeing the BRI as just one aspect of island-China relations.

This highlights a shortcoming in the manner in which the BRI has thus far been practiced. Is it possible or acceptable for a single country to take it upon itself to construct a framework for multinational collaboration, coordination, and mutually beneficial development? Can any one country truly succeed at creating an archipelagic network out of disparate island peoples and places that are driven by their own needs and centred in their own geographies?

It is, however, too early to write off the BRI. As the papers in this special section also show, there are aspects of the BRI that may hold out special promise for contributing to a peaceful, just, prosperous, and sustainable future for island communities around the world. Divergent local conditions require truly localised solutions, yet globalised environmental, economic, political, and cultural issues call for collaborative responses. The ongoing coronavirus (Covid-19) pandemic underlines the extent to which all places and peoples are 
now interdependent and interconnected, with all the messiness, complexity, potential for disaster, and potential for mutual assistance that this implies. The same connections and relations that grant islands strength also render them vulnerable (Grydehøj, Kelman, \& Su, 2020).

Going forward, if the BRI is to succeed, it must negotiate the tension between its aims of win-win development and policy coordination on the one hand and the impossibility of one state designing and designating a single future that is in everyone's interests on the other. The BRI as a whole must be developed multilaterally and with input from actors of all kinds in all places, including in island and archipelago states and territories. Only in this manner can the BRI's promise truly be realised.

\section{Funding}

This research is funded by the General Program of the National Natural Science Foundation of China, No. 51878592 and No. 71904060; Youth Program of National Natural Science Foundation of China, No. 51508498; Foundation of Zhejiang Province Philosophy and Social Science Planning Strategy Application, No. 19NDYD32YB; Foundation of Zhejiang Province Educational Committee (Grant Year 2018), No. 19NDYD32YB; Basic Public Welfare Research Plan of Zhejiang Province, No. LGN20E080002; and independent research program of Center for Balance Architecture, Zhejiang University.

\section{References}

Blanchard, J.M.F., \& Flint, C. (2017). The geopolitics of China's Maritime Silk Road Initiative. Geopolitics, 22(2), 223-245. https://doi.org/10.1080/14650045.2017.1291503

Blaxekjær, L.Ø., Lanteigne, M., \& Shi, M. (2018). The Polar Silk Road \& the West Nordic Region. Arctic Yearbook, 2018, 437-455.

Cai, P. (2017). Understanding China's Belt and Road Initiative. Lowy Institute.

Chen, J., Fei, Y., Lee, P.T.W., \& Tao, X. (2019). Overseas port investment policy for China's central and local governments in the Belt and Road Initiative. Journal of Contemporary China, 28(116), 196-215. https://doi.org/10.1080/10670564.2018.1511392

Davis, S. (2020). Islands and oceans: Reimagining sovereignty and social change. University of Georgia Press.

Davis, S., Munger, L.A., \& Legacy, H.J. (2020). Someone else's chain, someone else's road: U.S. military strategy, China's Belt and Road Initiative, and island agency in the Pacific. Island Studies Journal, 15(2), 13-36. https://doi.org/10.24043/isj.104

Damuri, Y.R., Perkasa, V., Atje, R., \& Hirawan, F. (2019). Perceptions and readiness of Indonesia towards the Belt and Road Initiative. Centre for Strategic and International Studies, Jakarta.

Depraetere, C. (2008). The challenge of nissology: A global outlook on the world archipelago, Part I: Scene setting the world archipelago. Island Studies Journal, 3(1), 3-16.

Flint, C., \& Zhu, C. (2019). The geopolitics of connectivity, cooperation, and hegemonic competition: The Belt and Road Initiative. Geoforum, 99, 95-101. https://doi.org/10.1016/j.geoforum.2018.12.008

Grydehøj, A., Kelman, I., \& Su, P. (2020). Island geographies of separation and cohesion: The coronavirus (COVID-19) pandemic and the geopolitics of Kalaallit Nunaat 
(Greenland). Tijdschrift voor economische en sociale geografie, 111(3), 288-301. https://doi.org/10.1111/tesg. 12423

He, B. (2019). The domestic politics of the Belt and Road Initiative and its implications. Journal of Contemporary China, 28(116), 180-195. https://doi.org/10.1080/10670564.2018.1511391

Herrero, A.G., \& Xu, J. (2019). Countries' perceptions of China's Belt and Road Initiative: A big data analysis. HKUST UEMS Working Paper, 2019-59.

Jones, L., \& Zeng, J. (2019). Understanding China's 'Belt and Road Initiative': Beyond 'grand strategy' to a state transformation analysis. Third World Quarterly, 40(8), 1415-1439. https://doi.org/10.1080/01436597.2018.1559046

Kwong, Y.H., \& Wong, M.Y.H. (2020). International linkages, geopolitics, and the Belt and Road Initiative: A comparison of four island territories. Island Studies Journal, 15(2), 131-154. https://doi.org/10.24043/isj.127

Li, C., Chen, J., \& Grydehøj, A. (2020). Island climate change adaptation and global public goods within the Belt and Road Initiative. Island Studies Journal, 15(2), 173-192. https://doi.org/10.24043/isj.134

Lim, K.S. (2018). China's Arctic Policy and the Polar Silk Road Vision. Arctic Yearbook, 2018, 420-432.

Liu, W., \& Dunford, M. (2016). Inclusive globalization: Unpacking China's Belt and Road Initiative. Area Development and Policy, 1(3), 323-340. https://doi.org/10.1080/23792949.2016.1232598

Liu, W., Dunford, M., \& Gao, B. (2018). A discursive construction of the Belt and Road Initiative: From neo-liberal to inclusive globalization. Journal of Geographical Sciences, 28(9), 1199-1214. https://doi.org/10.1007/s11442-018-1520-y

National Development and Reform Commission, Ministry of Foreign Affairs, \& Ministry of Commerce (2015). Vision and actions on jointly building Silk Road Economic Belt and 21stCentury Maritime Silk Road. Ministry of Foreign Affairs of the People's Republic of China. https://www.fmprc.gov.cn/mfa eng/zxxx 662805/t1249618.shtml

Nordin, A.H., \& Weissmann, M. (2018). Will Trump make China great again? The Belt and Road Initiative and international order. International Affairs, 94(2), 231-249. https://doi.org/10.1093/ia/iix242

Pant, H.V., \& Passi, R. (2017). India's response to China's Belt and Road Initiative: A policy in motion. Asia Policy, 24, 88-95. https://doi.org/10.1353/asp.2017.0025

Putri, H., \& Salim, W. (2020). The Maritime Silk Road's potential effects on outer island development: The Natuna Islands, Indonesia. Island Studies Journal, 15(2), 155-172. https://doi.org/10.24043/isj.136

Rodd, A. (2020). A road to island sovereignty and empowerment? Fiji's aims within the Belt and Road Initiative. Island Studies Journal, 15(2), 93-118. https://doi.org/10.24043/isj.128

Winter, T. (2019). Geocultural power: China's quest to revive the Silk Roads for the Twenty-First Century. University of Chicago Press. https://doi.org/10.7208/chicago/9780226658490.001.0001 
Xie, B., Zhu, X., \& Grydehøj, A. (2020). Perceiving the Silk Road Archipelago: Archipelagic relations within the ancient and 21st-Century Maritime Silk Road. Island Studies Journal, 15(2), 55-72. https://doi.org/10.24043/isj.118

Ye, F., Park, J., Li, C., \& He, Y. (2020). The relationship between China-South Pacific island countries tourism and trade in the context of the Belt and Road Initiative. Island Studies Journal, 15(2), 73-92. https://doi.org/10.24043/isj.126

Yu, T., \& Li, B. (2020). Island territorial disputes and China's 'Shelving Disputes and Pursuing Joint Development' policy. Island Studies Journal, 15(2), 37-54. https://doi.org/10.24043/isj.129

Zeng, J. (2019). Narrating China's Belt and Road Initiative. Global Policy, 10(2), 207-216. https://doi.org/10.1111/1758-5899.12662

Zhang, X. (2017). Chinese capitalism and the maritime silk road: A world-systems perspective. Geopolitics, 22(2), 310-331. https://doi.org/10.1080/14650045.2017.1289371

Zhang, Z. (2018). The Belt and Road Initiative: China's new geopolitical strategy?. China Quarterly of International Strategic Studies, 4(03), 327-343. https://doi.org/10.1142/s2377740018500240

Zhong, S., \& Wu, X. (2020). Indian Ocean island sustainable development in the context of the 21st-Century Maritime Silk Road. Island Studies Journal, 15(2), 119-130. https://doi.org/10.24043/isj.117

Zhou, W., \& Esteban, M. (2018). Beyond balancing: China's approach towards the Belt and Road Initiative. Journal of Contemporary China, 27(112), 487-501. https://doi.org/10.1080/10670564.2018.1433476 
Adam Grydehøj, Sasha Davis, Rui Guo, \& Huan Zhang 